\title{
PLATE GIRDERS WITH CORRUGATED WEBS
}

\author{
Hartmut Pasternak $^{1}$, Gabriel Kubieniec ${ }^{2}$ \\ ${ }^{1,2}$ Brandenburg University of Technology, Konrad-Wachsmann-Allee 2, 03046 Cottbus, Germany \\ E-mail: ${ }^{1}$ Hartmut.Pasternak@tu-cottbus.de; ${ }^{2}$ kubienie@tu-cottbus.de
}

Received 25 Sept. 2009; accepted 20 Jan. 2010

\begin{abstract}
Especially for the main frames of single-storey steel buildings the use of corrugated web beams, mainly with sinusoidal corrugation, has been increased very much during the last years. Due to the thin web of 1,5 mm to $3 \mathrm{~mm}$ corrugated web beams afford a significant weight reduction compared with hot rolled profiles or welded I-sections. Buckling failure of the web is prevented by the corrugation. The buckling resistance of presently used sinusoidal corrugated webs is comparable with plane webs of $12 \mathrm{~mm}$ thickness or more. Due to improvements of the automatic fabrication process corrugated webs up to $6 \mathrm{~mm}$ thickness became possible. Therefore the field of application of this beam type has been extended considerable. Even short span bridges are possible now. The dimensioning of corrugated web beams is ruled by the EN 1993-1-5 Annex D - it covers only web thicknesses up to $3 \mathrm{~mm}$. In the last years many tests and finite element simulations have been carried out. Regarding this background, these EN rules will be discussed and extended. Furthermore, additional proposals for patch loading and lateral-torsional buckling of girders with sinussoidal webs will be given.
\end{abstract}

Keywords: plate girder, sinusoidal corrugated web, stability.

\section{Introduction}

Especially for the main frames of single-storey steel buildings the use of corrugated web beams, mainly with sinusoidal corrugation, has been increased very much during the last years (Fig. 1). Due to the thin web of 2 or $3 \mathrm{~mm}$, corrugated web beams afford a significant weight reduction compared with hot rolled profiles or welded I-sections. Buckling failure of the web is prevented by the corrugation. The buckling resistance of presently used sinusoidal corrugated webs is comparable with plane webs of $12 \mathrm{~mm}$ thickness or more.

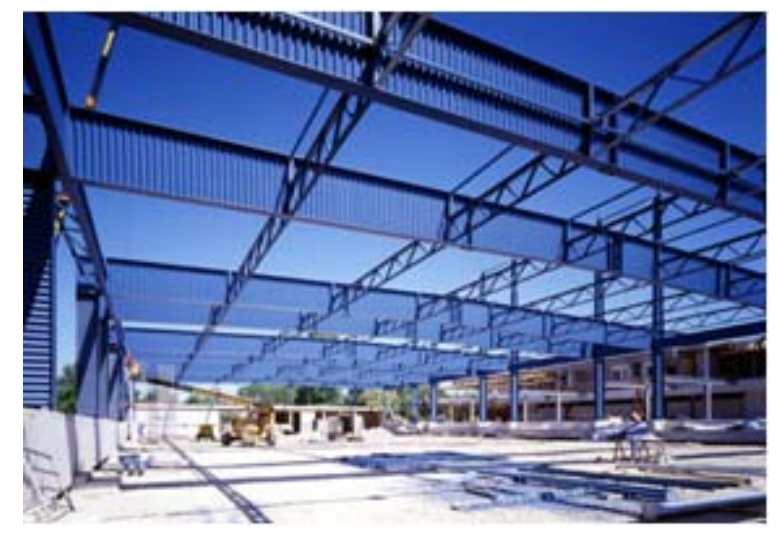

Fig. 1. Single-storey building

When corrugated web beam have been developed during the 60ies of last century, especially the profiling of the web and the welding was hand work. Due to the progress of welding technology an automatic fabrication process became possible.
Since the end of the 80ies of last century corrugated web beams with sinusoidal corrugated webs are produced by an automated production process. In 1988 the first machine for the production SIN-beams were developed by ZEMAN, Austria. These semi-automatic machines of the first generation were able to produce SIN-beams with parallel flanges and a web thickness of $2.0 \mathrm{~mm}, 2.5 \mathrm{~mm}$ or $3.0 \mathrm{~mm}$ (Siokola 1997).

\section{Automatic fabrication process}

The machines of latest generation are able to produce SIN-beams by a fully automated process (Pasternak et al. 2008). A more variable design of cross sections, a variety of web thickness, lower beam heights and smaller flange dimensions became possible. Furthermore tapered beams and machine-made web openings can be produced.

Actually there are around 10 production lines around the world. The automatic production (Fig. 2) of the following beam dimensions is possible:

- Web height 333, 500, 625, 750, 1000, 1250 and 1500 [mm]

- Web thickness 1.5, 2, 2.5, 3, 4, 5, 6 [mm]

- Flange thickness from 6 to 30 [mm]

- Flange width from 120 to 450 [mm]

The maximum beam length of $16 \mathrm{~m}$ corresponds to the maximum range of welding robots. Usually beam are shorter because of the limits for the transport, galvanizing etc. For tapered beams the maximum length is $12 \mathrm{~m}$. Due to improvements corrugated webs up to $6 \mathrm{~mm}$ thickness became possible. Therefore the field of application of this beam type has been extended considerable. Even short span bridges are possible now. The web material comes 
from a coil. It is unrolled and cut to length automatically by the machine. A so called "corrugator" forms the sheet to a corrugated web. The flanges has been already prepared and stored in special flange baskets. After the running-in of the web and flanges into the welding station all members are moved to the correct position, are pushed together and are welded by the welding robots.

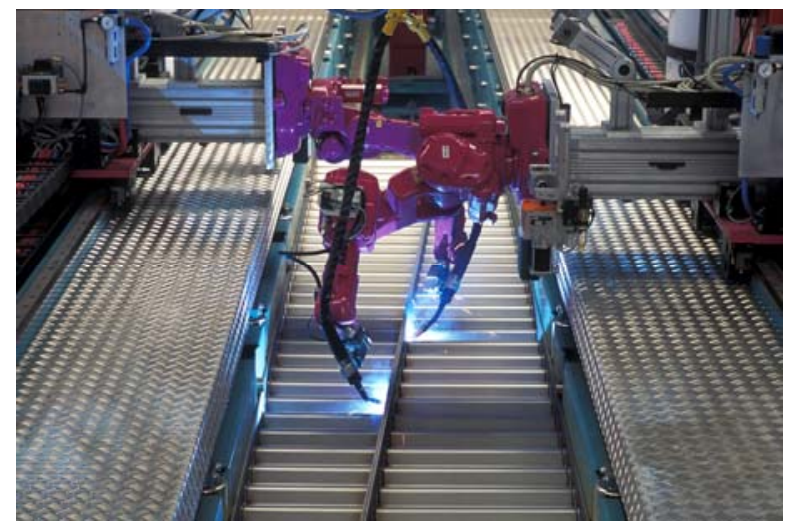

Fig. 2. Automatic production process

\section{Application examples}

The basic areas of use of girders with sinusoidally corrugated web are main single- or multi-span frames consisting of columns and rafters. In addition, there are also applications in heavy industrial buildings. Fig. 3 shows a crane way column and Fig. 4 a Gerber hinge, used in a multispan frame in a mill at Katowice, Poland (Pasternak, 2004). In the Innsbruck Stadium, Austria, extended for Euro 2008, $16 \mathrm{~m}$ long SIN beams are used as purlins (Fig. 5). Thanks to good distribution of mass within the cross-section, those girders can be characterised by high

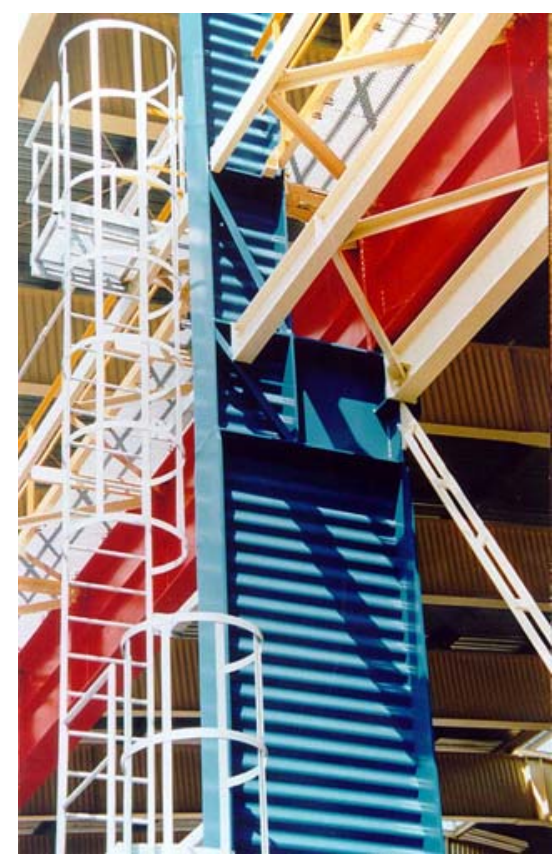

Fig. 3. Crane way column

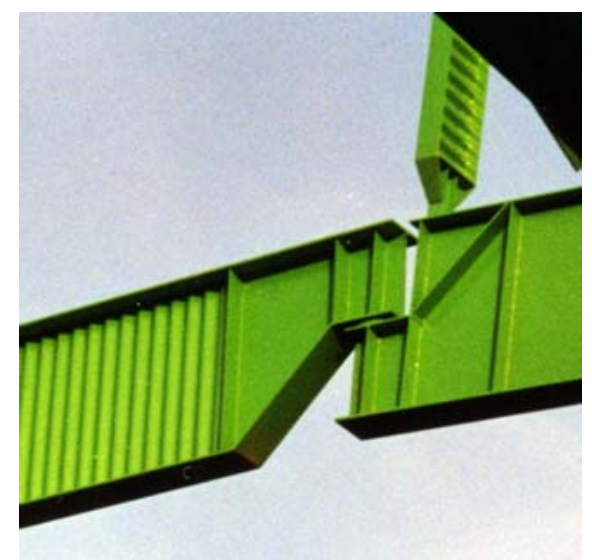

Fig. 4. Gerber hinge

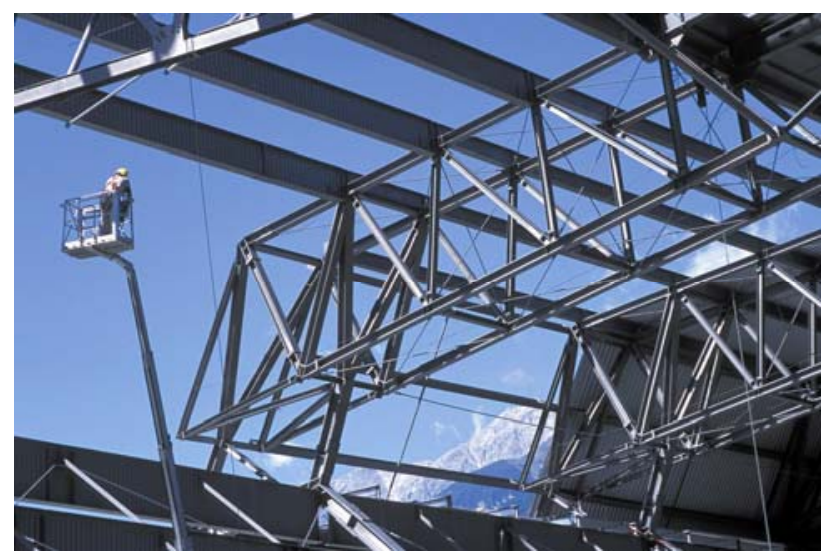

Fig. 5. Roof structure of Innsbruck Stadium (Wimmer 2008)

bending capacity with relatively low self weight. In comparison with traditional hot-rolled profiles, the reduction of self weight amounts even up to $40 \%$.

\section{Present state of codes}

\subsection{General}

Actually beams with corrugated webs are ruled by the Eurocode EN 1993-1-5, Annex D (EC-3 2006). There used to be older standards as well, e.g. the German DASt-Ri 015 from 1990. But these standards deal about beams with trapezoidal corrugated webs only (EC-3 2006). Only by consideration of additional papers (Pasternak et al. 1998) and expert opinions (Pasternak et al. 1998, 2008), it became possible to use this document for the calculation of sinusoidal corrugated webs. The EN 1993-1-5 gives rules for both trapezoidal corrugation and sinusoidal corrugation. Whereas the dimensioning procedure for trapezoidal corrugated webs bases on the tests results for sinusoidal corrugated webs, the latest test results are not considered by the given rules. Therefore the calculation procedure according to EN is comparatively conservative. The bearing behaviour of a beam with corrugated web is comparable with a lattice girder. Normal force and bending moment are carried by the flanges only. Due to the corrugation the web is not able to carry any normal stresses in the longitudinal direction of the beam. Therefore the web is loaded by shear force only. 


\subsection{Bending moment resistance of flanges}

To verify the bending moment capacity of a beam, the resistance of flanges against yielding and global and local buckling for the compression flange has to be taken into account. Lateral-torsional buckling of beam is verified by global out-of-plane buckling of the compression flange. The verification is a conservative assumption because the torsional stiffness is neglected. Local buckling of the flange (cross section class 4 ) is considered by the determination of a reduced flange width. A reduced yield strength $f_{y \cdot r}$ considers the influence of transverse bending moments. These moments are caused by the shear flow longitudinal to the joint of flange / corrugated web. It has to be taken into account for trapezoidal corrugated webs. Actually produced sinusoidal corrugated webs have a small corrugation height compared with the width of flanges. Therefore the influence of transverse bending moments is negligible.

\subsection{Shear force resistance of web}

The web loaded by shear force can fail due to yielding, local buckling and global buckling. The EN 1993-1-5 defines the reduction factor for global web buckling as follows (Fig. 6):

$$
\chi_{c, g}=\frac{1,5}{0,5+\bar{\lambda}_{c, g}^{2}} \leq 1
$$

where: $\chi_{c, g}$ is the reduction factor and $\bar{\lambda}_{c, g}$ the reference slenderness for global web buckling.
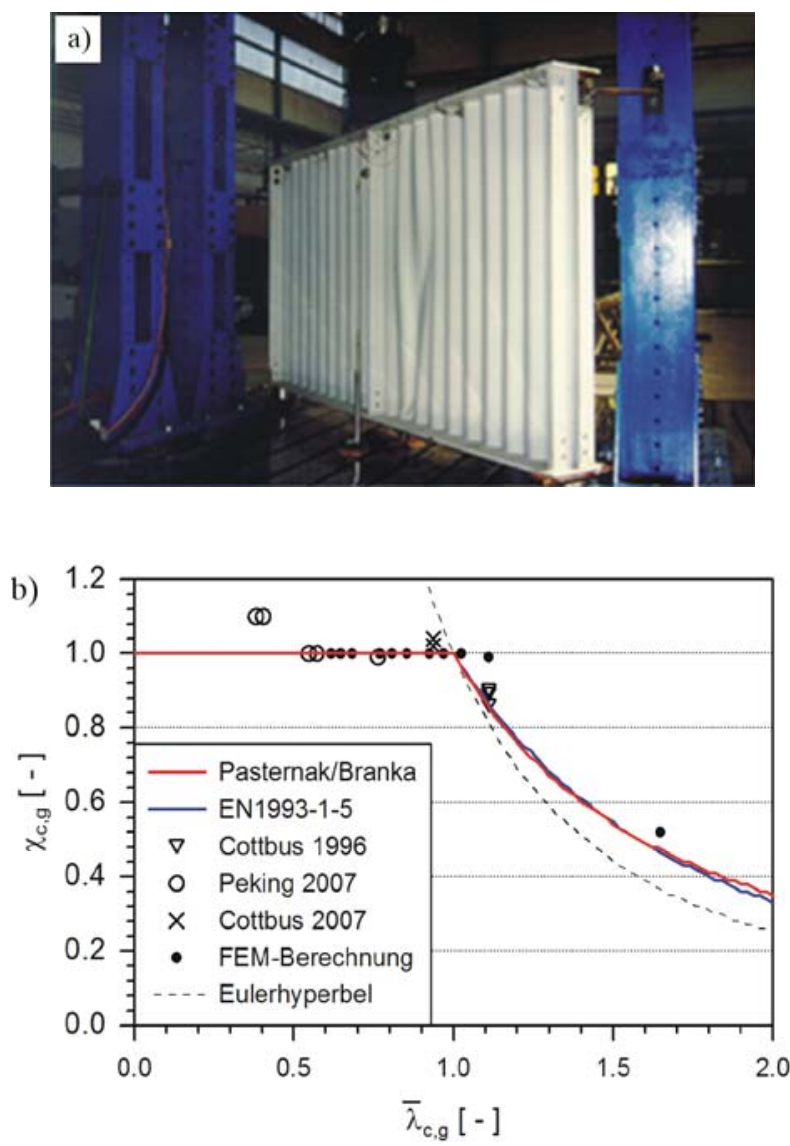

Fig. 6. Global buckling curve: a - test, b - curve and results according to (Pasternak et al. 1996, 1998, 2008)
For local buckling the following reduction factor is defined:

$$
\chi_{C, l}=\frac{1,15}{0,9+\bar{\lambda}_{c, l}} \leq 1,
$$

where: $\chi_{c, l}$ is the reduction factor and $\bar{\lambda}_{c, l}$ the reference slenderness for local web buckling.

\section{Global and local buckling of web}

For global web buckling the given rule matches the test results very well (Fig. 6). It was found by testing and FEM (e.g. Pasternak et al. 1998) that no local buckling occurs for all actually produced beams with sinusoidal corrugated webs. That means any reduction should be necessary for a reference slenderness smaller than 0,74 (area I of Fig. 7). A second reason for further research is the probably to large reduction factors for a reference slenderness greater than 1,5 (area II of Fig. 7). The reduction curve shows overcritical reserves of bearing capacity. This behaviour is typical for plate buckling and therefore understandable for trapezoidal corrugated webs that consist of plate elements. However, a sinusoidal corrugated web is mainly a shell structure. The overcritical reserve of the reduction curve of EN 1993-1-5 has to be proved.

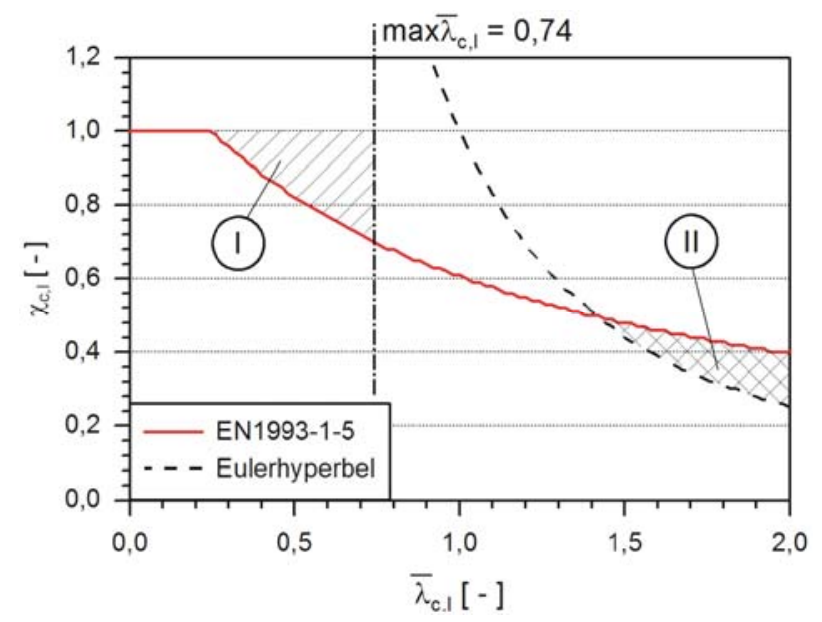

Fig. 7. Reduction curve for local buckling EN 1993-1-5

\section{Lateral-torsional buckling}

Concerning lateral-torsional buckling four tests and a large amount of FE simulations have been carried out (Hannebauer 2008). Tests and FE results in comparison with European buckling curves are given in Fig. 8.

\section{Patch loading}

In the parameter study girders with various forms of corrugation the patch load was investigated, the length and the amplitude of the wave were varied (Pasternak et al. 1989, 2004) (Fig. 9). From many series of FE simulations a simple approach of the ultimate load was developed

$$
F_{u l t}=10\left(\frac{W_{e l}}{I / t}\right)^{0,4} \cdot 2 \cdot f \cdot t \cdot f_{y, d},
$$


a)
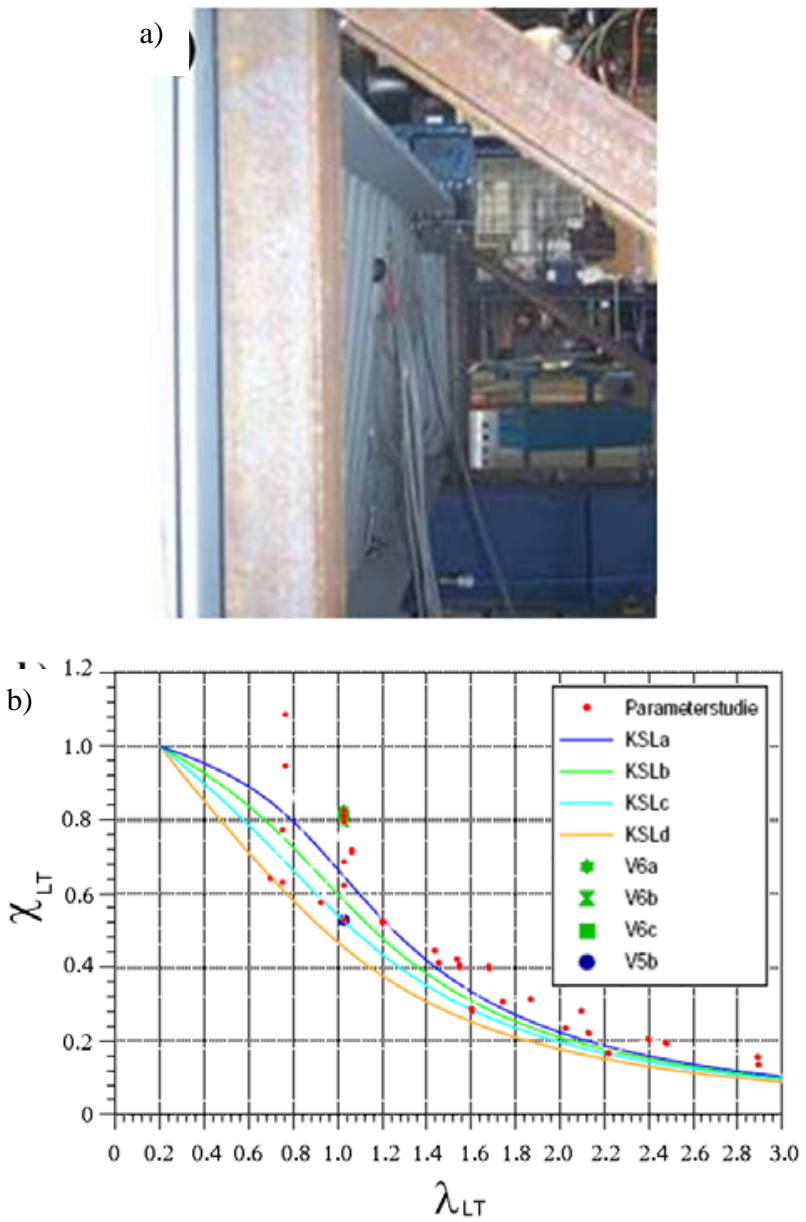

Fig. 8. Lateral-torsional buckling: a - test girder V6c, $\mathrm{b}$ - test and FEM in comparison with European buckling curves

where: $W_{e l}$ - effective section modulus of the flange; $I$ moment of inertia of a full wave about the horizontal axis of symmetry; $t$ - web thickness; $2 f, q$ - amplitude and length of the wave

$$
I=0,158 \cdot t \cdot q^{3}\left(\frac{2 f}{q}\right)^{2,12} .
$$

The domain of definition is limited to $3 \mathrm{~mm}$ web thickness and $100 \mathrm{~mm}$ load distribution length. Analyzing a failure state (Kozlowski 2007), this formula gives reasonable ultimate loads. An extension of this formula to web thicknesses of $6 \mathrm{~mm}$ is necessary.

\section{Interaction}

First interaction diagrams between the bending moment and shear force resp. patch load are given in (Pasternak et al. 2004).

\section{Present research}

At the Universities of Technology in Cottbus and Braunschweig there is carried out a research programme within the frame work of a national research project (AIF 2008). The main aim of the study is to describe influence of welding process on carrying capacity of girder with sinusoidally corrugated web. The analysed girder was $7 \mathrm{~m}$ long beam
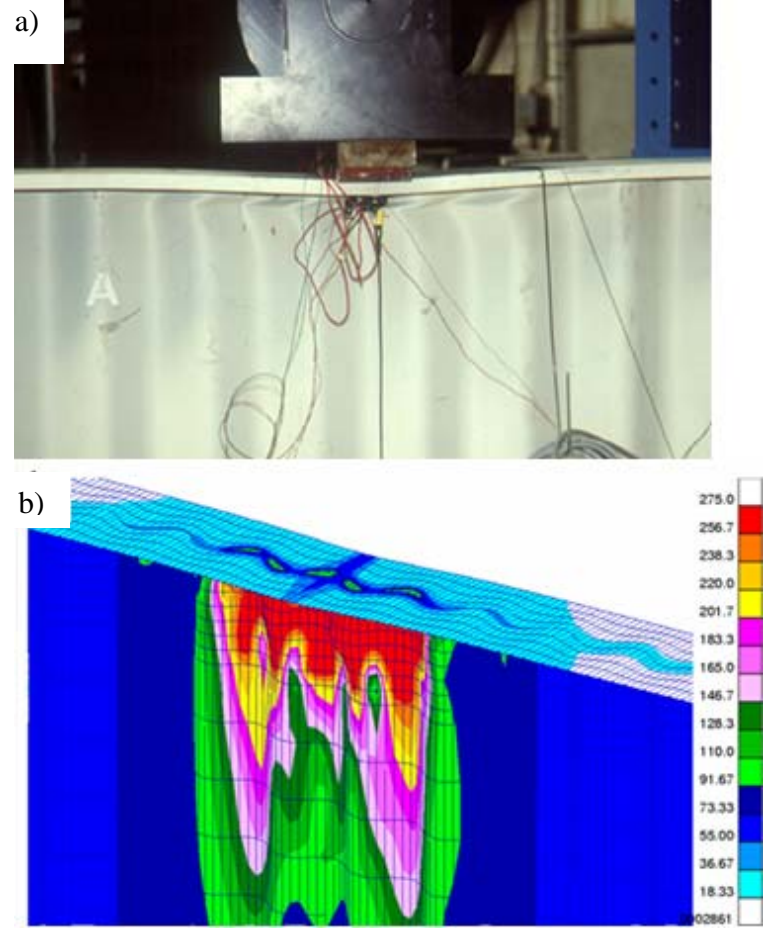

Fig. 9. Patch loading: a - test, b - FEM

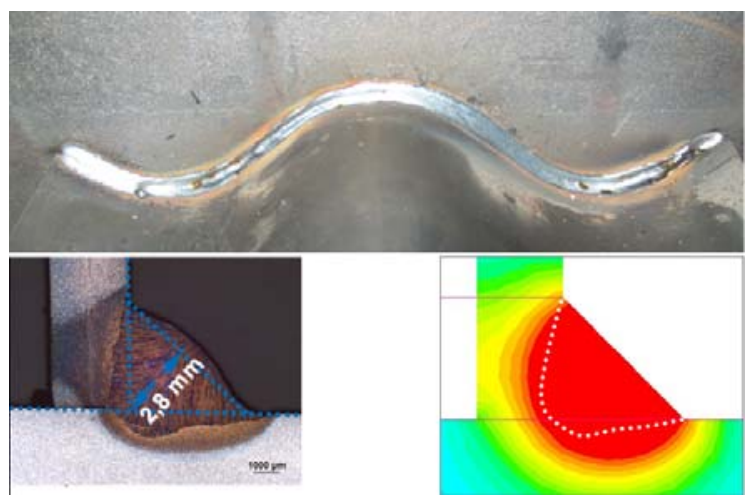

Fig. 10. Welding simulation

with flanges $25 \times 200 \quad[\mathrm{~mm}]$ and webs $3 \times 500[\mathrm{~mm}]$ (Fig. 10), loaded by two concentrated forces, each placed in distance $465 \mathrm{~mm}$ from a vertical axis of symmetry of girder. Two areas of investigations are distinguished i.e. local focused on welding simulations and global designed to describe behaviour of whole girder. The welding simulations showed that the average thickness of weld joining web and flange is about $2.8 \mathrm{~mm}$ and is accompanied by penetration of thermal source at width about $4 \mathrm{~mm}$ in every direction (Fig. 11). The residual stresses coming from welding process are important parameter especially in nonlinear analysis that is why it should be carefully analysed. Strain gauge measurements (Fig. 12) showed highly nonlinear normal stress distribution across the cross-section of flange especially in area of welding zone. This nonlinearity is much more visible in tension flange than in compression one, and can be an evidence of existing residual stresses coming from welding process which are superimposed with those from bending (Fig. 13 and 14). The comparison of diagrams representing dependence of normal stresses on 


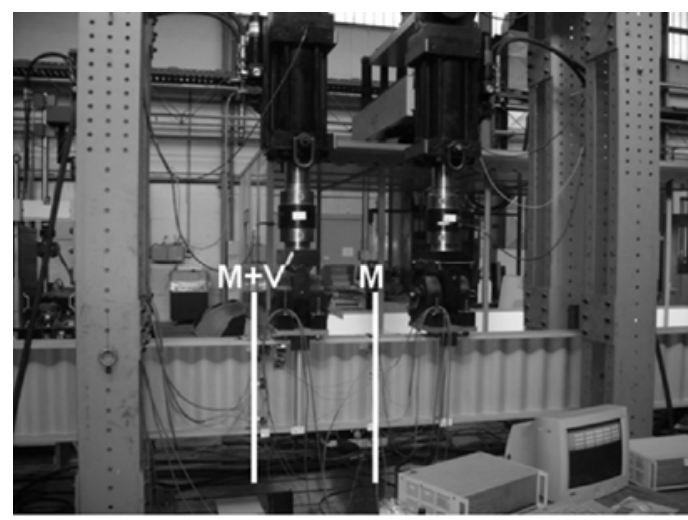

Fig. 11. Test specimen

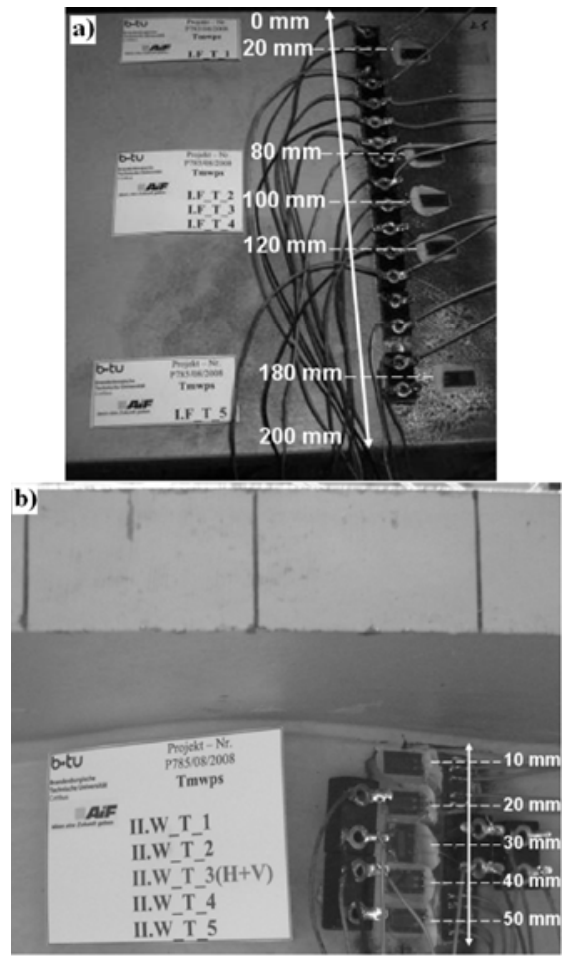

Fig. 12. Layout of gauges on flange (a) and web (b)

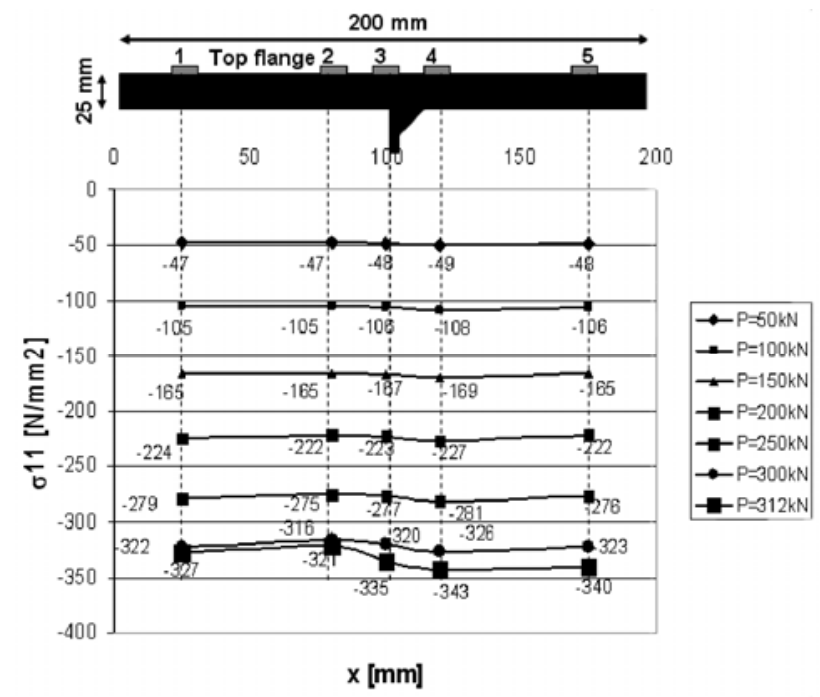

Fig. 13. Normal stress distribution in top flange load for example in points 1 and 3 (Fig. 15) showed that in case of point 1 the curves run together parallel while in point 3 are clearly diverse. This can be a result of influence of thermal residual stresses. Moreover there was described the width of web along which exist high normal stresses coming from bending. This width was estimated at $5 \mathrm{~cm}$ below the connection of the web and the flange (Fig. 16). That means that in very close vicinity of weld i.e. $50 \mathrm{~mm}$ there can be a superposition of normal stresses caused by welding and bending. The resultant normal stresses interact with those caused by shear force and there is a suggestion to subtract this area from shear area in design calculations. Additionally it has to be underlined that two effects i.e. increase of yield strength of material of web due to cold-forming process and existence of high normal stresses in mentioned above areas of web are not considered in actual design.

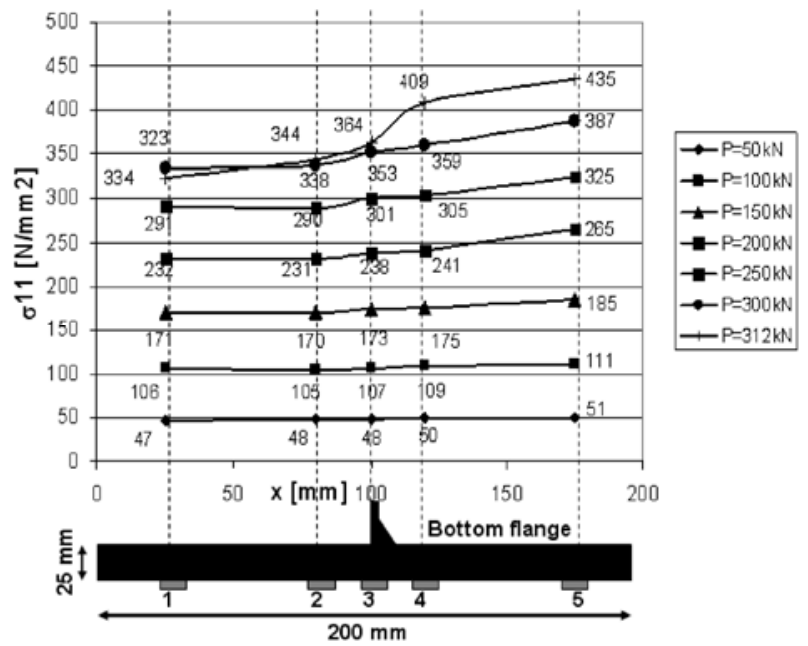

Fig. 14. Normal stress distribution in bottom flange
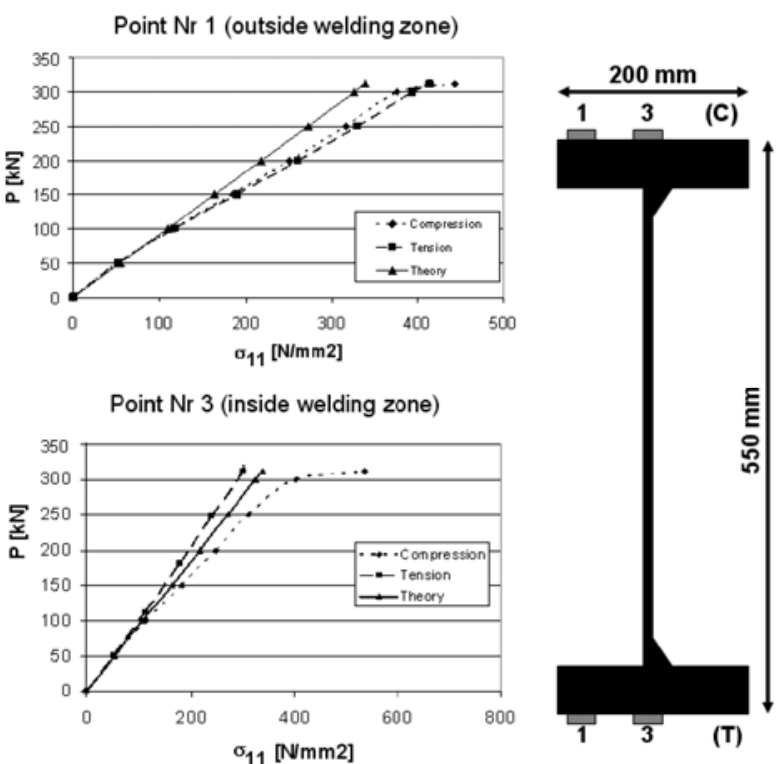

Fig. 15. Comparison of load-normal stress curve 


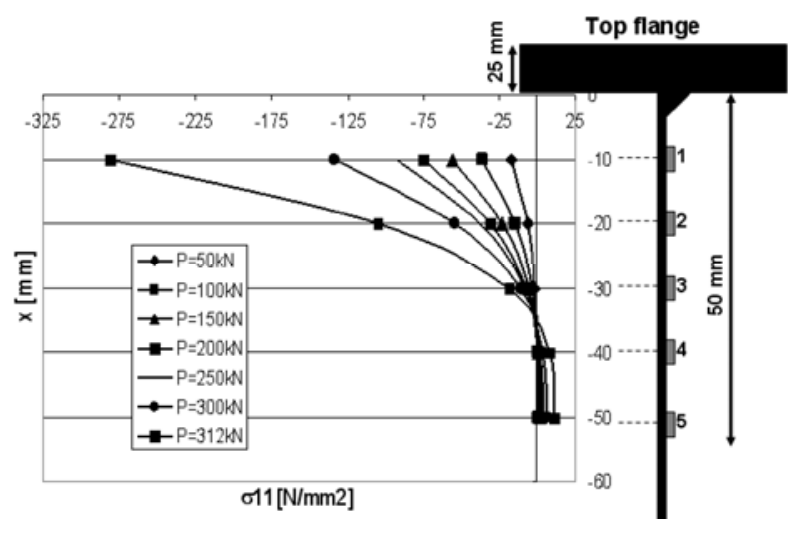

Fig. 16. Normal stress in web

\section{Conclusion}

EN 1993-1-5 Annex D rules have been discussed for actually produced sinusiodal girders. For those girders do not appear local buckling effects before the web reaches its yielding shear capacity. The buckling curve should be improved. Furthermore, additional proposals for patch loading and lateral-torsional buckling of girders with sinussoidal webs were given. Moreover tests showed nonlinear stress-strain relationship. This is a consequence of existence of thermal fields and initial stresses coming from welding of web to flanges and also from cold-forming process of web. These aspects are studied in a national research project, carried out in Cottbus and Braunschweig.

\section{References}

AIF Einsatz der Schweißsimulation zur systematischen Entwicklung verbesserter Modelle für die Berechnung der Tragfähigkeit komplexer Stahlleichtbaustrukturen P 785/ 08/2008 / IGF-Nr. 287 ZBG.
Hannebauer, D. 2008. Zur Querschnitts- und Stabtragfähigkeit von Trägern mit profilierten Stegen. Dissertation, BTU Cottbus.

Kozlowski, A. 2007. Failure state of roof structure with corrugated web's girders. Awarie budowlane, Szczecin (in Polish).

Pasternak, H. 1996. Gutachterliche Stellungnahme zur Querkrafttragfähigkeit von Wellstegträgern. Braunschweig/ Cottbus.

Pasternak, H.; Branka, P. 1998. Zum Tragverhalten von Wellstegträgern, Bauingenieur 73: 437-444.

Pasternak, H.; Branka, P. 1999. Tragverhalten von Wellstegträgern unter lokaler Last einleitung, Bauingenieur 74: 219-224.

Pasternak, H; Hannebauer, D. 2004. Träger mit profilierten Stegen, Stahlbau-Kalender 2004. Berlin, Verlag Ernst \& Sohn, 449-492.

Pasternak, H.; Robra, J.; Bachmann, V. 2008a. Corrugated web beams with increased web thickness, in Proceedings $5^{\text {th }}$ Europea Conference on Steel and Composite Structures, Graz, Austria 2008, 1161-1166.

Pasternak, H. 2008b. 2nd expert opinion on the shear capacity of girders with sinusoidally corrugated web. Braunschweig/ Cottbus 2008.

Siokola, W. 1997. Wellstegträger. Herstellung und Anwendung von Trägern mit profiliertem Steg, Stahlbau 66: 595-605.

Wimmer, A., et al. 2008. Stadion Innsbruck „Tivoli neu“ für Euro 2008 erweitert, Bauingenieur 83: 405-409.

Yan-lin, G.; Qing-lin, Z.; Siokola, W.; Hofer, A. 2008. Flange buckling behaviour of the H-shaped member with sinusoidal webs, in Fifth International Conference on ThinWalled Structures, Brisbane, Australia, 2008.

Eurocode 3 - Design of steel structures - Part 1-5: Plated structural elements, Annex $D$, European committee for standardisation (CEN): 2006.

\section{SUDE்TINĖS SIJOS SU GOFRUOTĄJA SIENELE}

\section{H. Pasternak, G. Kubienec}

\section{S a n t r a u k a}

Pastaruoju metu ypač vienaukščių pastatų plieniniams rėmams imtos plačiai naudoti sijos su pagal sinusoidę banguota sienele. Dèl plonų 1,5-3,0 mm storio gofruotujų sijų sienelių jų masè gerokai sumažèja, palyginti su karštai valcuotomis arba virintinėmis dvitėjo skerspjūvio sijomis. Sijos sienelès klumpamosios irties išvengiama dèl sienelès bangavimo. Šiuo metu naudojamų pagal sinusoidę subanguotų sienelių klumpamoji galia yra lygintina su $12 \mathrm{~mm}$ arba didesnio storio plokščių sieneliu galia. Patobulinus automatini gaminimo procesą gofruotają sienelę galima padaryti iki $6 \mathrm{~mm}$ storio. Todèl labai išsiplečia šių sijų naudojimo sritys. Sijos gali būti naudojamos nedidelio tarpatramio tiltams. Banguotasienių sijų projektavimo metodika aprašyta EN 1993-1-5 D priede, tačiau ji galioja tik sijoms, kuriu sienelès storis neviršija 3 mm. Pastaraisiais metais atlikta daug bandymų ir skaitinių eksperimentų baigtinių elementų metodu. Todèl šios EN projektavimo nuostatos bus aptariamos ir išplèstos. Be to, straipsnyje pateiktos papildomos rekomendacijos, kaip vertinti sijų su pagal sinusoidę banguota sienele uždètają apkrovą ir lenkiamaji sukamaji klupumą.

Reikšminiai žodžiai: sudètinès sijos, pagal sinusoidę banguota sienelè, pastovumas.

Prof. Hartmut PASTERNAK is involved in teaching, research and design of steel structures for more than 20 years. He is member in several National and International Committees (e.g.full member of the ECCS Technical Committee 8 "Structural Stability”, member of German subcommittee DASt-Ri015 “Girders with thin webs”, member of COST C25 action "Sustainability of Constructions”, member of the working group Eurocode 3 "Cranesupporting structures”). He has participated in numerous research projects (e.g. on thin-walled members and sheeting). Under his supervision 8 PhD's were completed. He has several publications in Journals and at Conferences (more than 100) and is co-author of books in German (4) and English (1) on steel structures. Moreover he is the editor of the journal "Bauingenieur” for steel structures.

Gabriel KUBIENIEC is a scientific assistant at the Brandenburg University of Technology Cottbus in Germany since 2009. He got PhD in 2009. His research interests include the behavior of thin-walled steel structures. He has 12 publications in Journals and at Conferences. 